\title{
Rethinking State, Civil Society and Citizen Participation. The Case of the Colombian Paramilitaries
}

\author{
Stacey L. Hunt
}

\begin{abstract}
Throughout Latin America, processes of democratization have coincided with increasing levels of violent crime, the privatization of justice and security, and widespread support for heavy-handed policing. The Colombian paramilitaries are perhaps the most notorious case of brutal violence committed against civilians with general support from both state and society. In this article, I explore the surprising amalgam of actors of which the paramilitaries are comprised. I illustrate the way in which their development was shrouded in and facilitated by legal ambiguity, and distinguish their war tactic of targeting the civilians from the guerrilla's strategy. Finally, I discuss the political success of the paramilitaries in terms of their land and wealth consolidation, their insertion into the political science, and their legal demobilization. I conclude by pointing out several prevalent impediments to our understanding of the paramilitary phenomenon, be they silences or biases, and I suggest conceiving of paramilitary violence not merely as havoc wrecked in the margins of the state, but as a central component of contemporary governance.
\end{abstract}

Keywords: paramilitary; Colombia; violence; privatized security; demobilization

\section{Introduction}

Nearly every country in Latin America ended a civil war, signed a peace treaty, or replaced authoritarian dictatorships with democratically elected governments in the late $20^{\text {th }}$ century. Yet violent crime continued to rise throughout the region, creating the greatest threat to, or flaw of, democracy in Latin America in the $21^{\text {st }}$ century. ${ }^{1}$ Citizens are said to live in perpetual fear, leading them to support heavy-handed and often illegal measures to deal with perceived criminals (Rotker 2002; Koonings and Kruijt 1999). Lynching and other forms of communal justice are now a notorious problem in the region, as poor citizens take justice and security provision into their own hands (Goldstein 2004; Snodgrass Godoy 2006; Benson, Fischer/ Thomas 2008; Vilas 2008). There has been an explosion of private security companies, widespread popular support for vigilante justice and autocratic leaders, a steady demand for increased policing, and mass opposition to human rights, which are seen as special treatment for criminals by many citizens whose own

1 In addition to Colombia (1991), Ecuador (1998), Brazil (1988), Argentina (1994), Peru (1993), Paraguay (1992), Venezuela (1999), and Guatemala (1985) all rewrote their constitutions to decrease violence by transitioning to democracy and increasing citizen participation. 
physical well-being is extremely precarious (Holston and Appadurai 1999, 15). As if this were not enough, this dual move toward state-led militarization and the privatization of justice are not merely products of widespread violence, but actually create insecurity, as well, in an ever-intensifying cycle of violence and militarization (Caldeira 2000).

In Colombia, this privatization of justice in the face of rising violent crime at the moment of democratization took on astonishing proportions. Colombia drafted and approved a new Constitution in 1991 in the face of a wave of violence that threatened to undermine the state's legitimacy. Yet levels of violence only continued to increase after the adoption of the new constitution, and have remained at epidemic proportions since. As with elsewhere in the region, privatized security and violence have spurned each other on. The Colombian paramilitaries were the largest, most organized, most violent, and most privatized security force in the hemisphere. Their exponential growth and the violence they enacted from the early 1980s until their demobilization in 2005 proved is yet largely incomprehensible. The paramilitary forces massacred thousands of communities, killed off entire political parties, and made torture a public ritual. And in the end, they succeeded in overseeing one of the largest re-distributions of wealth in the history of the country, establishing themselves as legitimate political actors, and avoiding any form of redress for their illegal gains through possibly the largest collective demobilization of paramilitary troops in the world.

In the more than 20 years since the Colombian state recognized the paramilitaries as the main perpetrators of violence in the country, surprisingly few studies have explored this phenomenon that has been singularly influential in shaping the country's contemporary landscape, physically, as well as politically. Many of the numerous "surveys" on violence in Colombia either completely ignore or radically marginalize the role and existence of paramilitaries (e.g. Bergquist/Peñaranda/Sánchez 1992, 2001; see Cubides 2005, $89)^{2}$ The limited number of studies that have recently been produced have largely fo-

2 It must be noted that violence directed at academics, independent researchers, and journalists by paramilitaries explains many of these silences. Scholars, professors, independent researchers, and journalists have a long history of being killed and intimidated by paramilitary groups in Colombia. Forty-five journalists were killed in Colombia from 1995 - 2006, making it one of most violent places in the world for journalists and creating a well-recognized environment of self-censure (see Inter-American Dialogue and the Foundation for the Freedom of the Press, FLIP, international meeting Bogotá, April 3-4, 2008). Mario Calderón and Elsa Alvarado, researchers at the Center for Public Research and Education (Centro para la Investigación y Educación Popular, CINEP), along with Elsa's father, on May 19, 1997. Paramilitary leaders Fidel and Carlos Castaño ordered the killings, but were never tried for the crime, while the hit man, Juan Carlos González Jaramillo was sentenced to forty years of prison in March of 2009. Paramilitaries threatened the academic Alfredo Molano, published along with his response in the prominent magazine Cambio 16 (August 25, 1997). Since their supposed demobilization, paramilitaries have continued to intimidate and murder intellectuals and students. They have systematically harassed human rights groups, including the student human rights committee (Comité de Derechos Humanos Gustavo Marulanda) on the University of Antioquía campus where paramilitaries killed one former student on March 12, 2009 after sending an email threat out to student members informing them that they were "military" targets and they had a week to leave the city or they would be killed (El Tiempo, El Espectador), and the Mesa Departamental de Derechos Humanos, at the University of Quindío on January 13, 2009 , comprised of both professors and students. Scholars that conducted extensive research on paramilitary-politician links outside of Bogotá refused to publish the data they gather indicating said connection in their book, Parapolitica, la ruta de la expansión paramilitar y los acuerdos político, for fear of reprisals. The scholarship presented alternative data on voting patterns, instead, but three of them were threatened anyway and had to exile themselves or live with a permanent bodyguard (Duncan 2009). 
cused on filling the paucity of factual information regarding the paramilitaries. While starting to increase our empirical knowledge of the paramilitaries, these descriptive studies have also made evident the difficulty of gathering information about the topic and the urgent need for theorizing the paramilitary phenomenon.

Scholars wholly underestimated the size and scale of the paramilitary phenomenon. Their political intentions went unnoticed and caught intellectuals and policy-makers alike off-guard. The intellectual community did not foresee the paramilitary demobilization, indeed, insisting that they were in essence a counter-insurgency force that would only disappear with the defeat of the guerrilla (see Cubides 1999, 2001, 2005). Scholars still do not agree as to whether the paramilitaries are the tool of a terrorist state or whether the illegal, irregular armed forces victimize an already besieged state (Pizarro 2004). Paramilitaries are said to provide security in the margins, where the state is weak, at the same time they are said to terrorize civilian populations at the bequest of an overpowering state (Valencia 2007). Scholars do not even agree on how to conceptualize the paramilitary's origin and development, creating multiple and competing paradigms that attempt to capture the shifting dynamics (Tate 2007; González/ Bolívar/Vázquez 2003).

In this paper I argue that paramilitaries must be understood as a tool of governance that has restructured social relations of power. Paramilitaries are neither a product of civil society that victimize the state, nor the mere tool of a terrorist state. Paramilitaries do not fill in the interstices of the state, compensating for it where it is weak or absent, and nor are they the product of an overbearing state. Rather, the Colombian paramilitaries must be understood as a mode of governing that is central to the inter-related process of state and citizen construction. While most scholars assumed that the rise of the modern nation-state would gradually eliminate or contain violence as the state increasingly monopolized the power of physical coercion and regulated society, violence continues to play a key role in the formation and transformation of modern nation-states (Coronil/Skurski eds. 2006). The sovereign nation-state is not the bedrock of "civilized" international order; rather, its very power is garnered from excessive and exceptional violence and the ability to create and exclude "bare life" (Hansen/Stepputat eds. 2006; Agamben 1998; Foucault 1980). Irregular armed forces were not just the foundation of Western states, rather they are constituent of modern states and governance as well (Tilly 1985; Davis/Pereira eds. 2003; Roitman 2004). The violence they invoke does not just destroy, but also regulates bodies, creates meaning, and structures life (Hansen/Stepputat eds. 2006; Hardt/Negri 2001). Far from being "besieged" or victimized by uncontrollable violence, the Colombian state uses violence as a tool of governance (Valencia 2007; Romero ed. 2007, 10; Sanford 2004, 256). ${ }^{3}$ This on-going process of state construction involves citizens in a dialectic of state and citizen formation that transcends understandings of the paramilitaries as either tools of a terrorist state or violent eruptions of civil society that besiege the state.

In this paper, I seek to transcend binary understandings of the Colombian state and society that frame paramilitaries as a product of either one or the other that attacks the remaining element. In doing so, I first take stock of the existing literature on paramilitarism in Colombia. Building on the descriptive studies that currently exist, I propose using the

3 Indeed, violence in Colombia is most acute in precisely the areas where the state is most present, in terms of the highest density of public functionaries and greatest public expenditure per inhabitant (Llorente et al 2001). 
Colombian case to further our theoretical understanding of the relationships between state and society as witnessed through privatized forms of security and justice. Although single cases cannot alone prove a hypothesis, they are excellent for theory building, disproving existing theories, and setting a research agenda (Gerring 2004). While pointing out the strengths and weaknesses, silences and gaps of existing studies on paramilitarism in Colombia, I will simultaneously establish the parameters of a future research agenda and contribute to a growing body of theory on the relations between state and society in an era of privatized and endemic violence.

In the first section, I explore the particular confluence of civil society actors, state agents and institutions, and illegal economies that converged to create the Colombian paramilitaries. In the second section, I discuss the legal frameworks constructed to foster and institutionalize the paramilitaries. In the third section I illustrate the particularities of the paramilitary violence, primarily, that they do not fight either the guerrilla or the state but rather target the civilian population. In the fourth section, I discuss the paramilitary demobilization and successful insertion into local and national political arenas. In the fifth and final section, I highlight both future areas of research and theoretical problems in current research, suggesting ways in which to improve our empirical study of the Colombian paramilitaries such that it might lend to our theoretical understanding of the ongoing and inter-related processes of state and citizen construction in the midst of widespread privatized violence.

\section{Identifying Agents: The Paramilitary Amalgam of Actors and Interests}

Naming the armed groups that comprise the contemporary paramilitaries in Colombia has been a highly political and contested project (see Cubides 1999, 167-170). Paramilitaries continue to call themselves counterinsurgent or self-defense forces, such as the United Colombian Self-Defense Forces (Autodefensas Unidas de Colombia, AUC). At least one scholar has proposed using "anti-insurgent" instead of counter-insurgent, in order to denote the paramilitary's use of anti-communist rhetoric but failure to engage in physical combat with the guerrilla (Salazar 2007, 62). Many observers combine the guerrilla, the military, and paramilitary groups together under the ubiquitous "armed actors." Others have contested the use of "actor" to denote the paramilitary forces, arguing that the term "actor" connotes rational actions, group consciousness, and an elaboration of goals and strategies related to articulated group interests, all of which transform private economic interests into a political agenda and lend toward the recognition of paramilitaries as political actors (Cubides 2001, 136). In the late 1980s and early 1990s, the state and most scholars were most concerned with groups of "private justice" (see Uprimny 1990), and President Barco explicitly stated that the term "paramilitary" was a misnomer (Decree 1194 of 1989). Virtually nobody has systematically labeled the troops as death squads, although their actions are compatible with this term. Indeed, only since the turn of the century has the label "paramilitary" been broadly adapted. "The term "paramilitaries' is generic and comprehensive and it best captures the essence of the amalgam forming in the most recent period," (Cubides 2001, 130).

"Paramilitary" encompasses a broad spectrum of groups including urban self-defense and extortion groups (combos), drug cartels, mafia-style organized crime, private armies, rural self-defense groups, and paid assassins (Espinal et al 2007, 123; Uprimny 1990, 
131). While the paramilitaries continue to be heterogeneous in their nature, character, and composition, there is a general consensus over their core components. Contemporary paramilitaries emerged from the confluence of six components: 1. local, regional, and national political elite 2. local, regional, and national economic elite, particularly large land owners 3. drug traffickers and the drug economy 4. the armed forces 5. big business, particularly that of livestock, emeralds, oil, and bananas 6. rural self-defense cooperatives (ICG 2007, 3; González/Bolívar/Vázquez 2003, 61). These institutions consisted of myriad individuals with competing interests, as well. The paramilitaries are "a precarious amalgam of unlike components, its contingency an authentic garbage dump, where all sorts of turncoats have gone to rest: ex-militaries that are fleeing justice, ex-guerrilla, active or retired drug traffickers, victims of the guerrilla and the extortive kidnapping with their personal vendetta, corrupt functionaries fleeing preliminary investigations - including those who emptied the coffers of the publicly subsidized health system - forced recruits, including child soldiers from wealthy families, and soldiers whose profession, and even vocation, is making war," (Cubides 2005, 94). Even seemingly antagonistic individuals have found a common home in the paramilitaries. Indeed, so many paramilitary fighters are guerrilla deserters that scholars termed the phenomenon as the "porosity" of the armed actors and the "flow" of combatants (porosidad y flujo) (Uribe 2001). ${ }^{4}$

Given these unlikely bedfellows, paramilitaries are comprised of uncomfortable and shifting alliances. They dabble in violence, the drug trade, and local and national politics. Paramilitaries provide security for large landowners and big business, like ranchers, the palm oil industry, banana companies, emerald production, oil extraction, and drug traffickers, while creating insecurity for the poor, workers, non or small landowners, women, the legal left, social activists, and all "marginal" populations, such as sex workers, youth, and gender non-conformists (Amnesty 2004). Paramilitaries exercise direct influence over the political organization and dynamic of region governance, including controlling elections, selecting who can occupy public office, and determining how the resources of the state will be invested in the region. They regulate property rights and administer justice, and even control demographics by deciding what type of populations can inhabit their zone, by killing or displacing those they consider undesirable (Duncan 2005, 27-8).

What distinguishes the paramilitaries from other groups involved in similar illicit activities, such as ordinary mafias and drug cartels, are their political ambitions. Paramilitaries are not reducible to self-defense forces or death squads, because they constantly seek to expand into and take control over new political, territorial, and economic spaces (Romero 2003, 38; Duncan 2005). ${ }^{5}$ This offensive character is shaped by the confluence of

4 Paramilitary fights were actively recruited from various guerrilla groups, including the Youth Communists (Juventud Comunista) and the ELN (Espinal et al 2007, 125; Cubides 1999, 159). More than 200 EPL fighters, who were previously targeted by the paramilitaries, joined the ranks of the ACCU after they demobilized (Cubides 2001, 138). Many top paramilitary commanders were previously among the guerrilla ranks. For example, the commander of the paramilitary incursion into Barrancabermeja was Camilo Morantes, a deserter of FARC (Cubides 2005, 93). Similarly, Vladimir, one of the most renowned paramilitary fighters for his grotesque violence, was previously a commander of the FARC $9^{\text {th }}$ Front. Marcelino Panesso, Rodríguez Gacha's right-hand man was also a FARC deserter, as were many of Carlos Castaño's special advisers.

5 "The term "señores de la Guerra" refers to the societal protection and coercion by armed factions above and beyond the democratic state's capacity to exercise a minimal degree of monopoly over violence. Unlike mafia networks, which regulate certain transactions and activities, the scale on which the 
military and elite interests. The rapid growth of the paramilitaries in the late 1980s was in direct response to success of electoral left. As demobilized guerrilla groups and the political left became electorally successful and combat groups entered into negotiations with the government, established power hierarchies were threatened, giving rise to elite support for paramilitaries in order to buttress their class position (Romero 2003, 41). Similarly, the abrupt expansion and federalization of the paramilitaries in the late 1990s was a direct response by the elite to their threatened class position as the FARC negotiated with the government (Valencia 2007, 8; Romero 2003). At both points, traditional political and economic elites supported the paramilitaries in order to reinscribe floundering class relations and an archaic social order threatened by the growth of social movements and the legal left (Duncan 2005, 49). "Some of the local elite allied themselves with the (paramilitary) alliance as a way to maintain hegemony and exclusive control over regional power and as an easy and quick way to recover regional power where they had lost it to opposition groups or civic, popular, or peasant movements. This objective was met by the physical elimination, the disappearance, and the forced displacement of the leaders and their social bases," (González/Bolívar/Vázquez 2003, 61).

This elite insecurity over threatened class relations coincided with increased pressure on the military to reduce human rights violations and project the image of a regime concerned with human rights, democracy, and civil liberties. Democratization processes in the late 1980s and early 1990s opened the country up to increasing international scrutiny, and required the military to distance itself from the human rights abuses it had systematically employed in it's battle against the communist insurgency, precisely at the moment when this insurgency was gaining incredible force. Civilian authorities weakened the power of the armed forces while tolerating paramilitary repression of social movements and the legal left, effectively criminalizing the legal left and decimating civil society (Avilés 2006, 385). The death squads were supported by multiple branches of the state, including politicians, bureaucrats, and military at all levels, in part so that they would perform the dirty work historically undertaken by the state military while distancing the military from critiques of human rights abuses. ${ }^{6}$ As early as 1986, the chief national prosecutor reported that army officials used death squads as "armed fronts, as hired killers who could do unofficially what was not permitted officially," (Pearce 1990). The paramilitaries replaced the armed forces as the leading source of human rights violations in the early 1990s, creating an optical illusion, making illegal violence seem external to the state and holding the state up as the protector of the people while numerous branches simply diverted that violence to the paramilitaries.

"señores de la Guerra" threaten and protect communities is so extensive that they constitute real States," (Duncan 2005, 27).

6 The state needed to distance itself from a rather dirty military past during which the military committed frequent forced disappearances and torture. For example, President Turbay-Ayala (1978-1982) called a state of siege and in 1980 over 8,000 Colombians were detained for "political reasons" and tried in military courts (Avilés 2006, 386). 


\section{Shrouds of Legal Ambiguity: National Security and Narco-Terrorism}

Contemporary paramilitaries have tenuous legal underpinnings to Cold War legislation that allowed for the training and arming of civilians by the military in order to assist in the fight against communism. Private citizens were first called to assist the military in its struggle against the guerrilla in 1962 under US advice to President Guillermo León Valencia (1962-1966) to set up "irregular units" trained to "execute paramilitary, sabotage and/or terrorist activities against known communist proponents," (as quoted, Dudley 2004, 96). The U.S. National Security Doctrine of the time openly relied upon civilians to fight and win the "war against communism." Presidential Decree 3398 of 1965, adopted permanently by Law 48 of 1968, legalized this militarization of civil society, allowing for the organization and arming of civilians into militias in order to help the military "maintain strong contact with the people" and "work with civilians" to achieve security.

These military initiatives coincided with drug traffickers and large landowners in the early 1908s. In 1981, the Minister of Defense under President Belisario Betancur (19821985) drew upon the 1965 decree in order to pass a law that made rural poor "give" service on weekends to "self-defense troops" designed to combat the guerrilla. In that same year, the FARC killed the prominent landowner Jesus Castaño; his sons formed the modern day "paramilitaries" by avenging his death through a killing rampage carried out with machetes (Dudley 2004, 118). In 1982, the Minister of Defense, General Landazabal, gathered representatives of the military, large cattle ranchers, businessmen, powerful politicians, and members of the Medellín drug cartel in an official meeting in Puerto Boyacá, to pitch in money, support, and men to work as the extra-legal arm of the military in their fight against communism. The unlikely bedfellows of rural cattle ranchers, urban drug traffickers, and the military came together at this moment over their hatred for the guerrilla, which had been extorting the ranchers and kidnapping family members of drug lords who were willing to pay high ransoms. Drug baron Pablo Escobar started the group Death to Kidnappers (Muerte a Secuestradores, MAS) after the guerrilla kidnapped several of his colleagues, and the death squad joined hands with the military and the cattle ranchers in their fight against the guerrilla. Landazabal launched the XIV Military Brigade in the same region in order to support the activities of the death squads. This area along the Magdalena River between Puerto Berrío and Puerto Boyacá would form the epicenter of paramilitary activity as the armed forces provided information, cover, training, and guns to the death squads (Dudley 2004, 42-43; González/Bolívar/Vázquez 2003; Medina Gallego 1990). By 1983 Amnesty International reported more than 800 extrajudicial executions in the region, and school enrollment in the municipality of Puerto Berrio shrunk by $70 \%$ as teachers and students fled the slaughter (Dudley 2004, 42-43).

As early as 1987 even the government's own statistics showed paramilitary groups to be responsible for more civilian deaths than all the guerrilla groups combined. César Gaviria, then Minister of Government, acknowledged in parliamentary debate the presence of some 140 paramilitary groups throughout the country (Cubides 1999, 174-5). Two years later, the Colombian Government's Security Office produced the "Paramilitary Dossier." This secret internal document was leaked to the press and published by the prominent weekly magazine, Semana (Edition 362, April 17, 1989). The dossier detailed the collusion of various disperse elements in the creation of the paramilitaries. It noted the reliance of the paramilitaries on the drug economy, primarily by providing "security" for drug dealers who bought massive tracks of land in order to launder money. It also documented the participation of military officers who gave logistics, information, intelligence, 
consultations, and trainings to the paramilitaries. The document furthermore noted the collusion of local, regional, and national state officials, bureaucrats, and politicians with the paramilitary forces. Finally, it made mention of both the support by big businesses, particularly the cattle, banana, emerald, and oil industries, as well as a certain level of popular support by sectors of the population tired of violence and intimidation by the FARC.

The legislative and executive branches of the state responded with a flurry of inactivity and willful disengagement. A series of presidential decrees in 1989 failed to disband or even nominally make illegal the existing death squads, merely requiring, instead, presidential approval before making new ones (Decree 815 of 1989, Decree 1194 of 1989). ${ }^{7}$ A commission was established to study the "paramilitary" problem, but it never met; in any case, it was comprised of politicians who were directly involved in the death squads and openly supported the "private justice groups" (Decree 813 of 1989). A special police force dedicated to the elimination of paramilitary groups was created, but explicitly adopted a pro-death squad policy and changed its mandate to anti-drug enforcement (Decree 814 of 1989; see Aviles 2006). In the 1991 National Strategy Against Violence there was still no mention of state-linked death squads, and paramilitaries were reduced to death squads that carry out social cleansings. A "Coordinating Committee for the Fight against Self-Defense Groups" was created under President Pastrana in 1999, but a year later, it had still not met (Aviles 2006, 400). The military components of the U.S. and Colombian governments continued to support death squads without establishing a legal framework for them, as well. Both governments worked closely with Los Pepes (People Persecuted by Pablo Escobar), a paramilitary group started by the Castaño brothers, Carlos and Fidel, that massacred family and friends of the famous drug baron, Death to Kidnappers (MAS), headed up by Escobar himself, and Diego Murillo, known popularly as "Don Berna," in operation Orion to take over Comuna 13 in Medellín (Avilés 2006, 395, ICG 2007; see also Dudley 2004).

With the abandonment of the legislative framework from the 1960s, paramilitaries and their supporters sought new legal channels through which to legitimize and promote the creation of paramilitary groups. These efforts culminated in presidential Decree 356 of 1994, the Private Security and Vigilance Statute (Estatuto de Vigilancia y Seguridad Privada), which allowed anyone to establish a private security firm in order to provide for his or her own security. This decree created the legal framework for the Convivir (Rural Vigilance Associations). With little oversight but a great deal of military and institutional encouragement, the Convivir provided the legal instrument for the paramilitary expansion, serving as the legal branch of the death squads under the direction of Salvatore Mancuso while the Castaño brothers, Fidel and Carlos, headed up the non-legal factions (Martínez 2004; Valencia 2007, 22-3). The first President of Convivir was the owner of a banana plantation who oversaw the efforts to "pacify" his workers in the region of Urabá

7 In 1989 President Barco suspended Law 48 of 1968 that allowed the military to organize civilians into "self-defence" troops. The Supreme Court declared the articles allowing for the distribution of weapons to civilians unconstitutional, and in June 1989, the government established criminal penalties for either civilians or members of the armed forces who recruited, trained, financed, or otherwise participated in paramilitary forces without the approval from the President and Ministry of Defence (Decree 1194 and Decree 815 of 1989). 
through massacres (Aviles 2006, 398). ${ }^{8}$ There were already 414 Convivir across the country in 1996 when a judge ordered its director, Salvatore Mancuso, to be arrested. Mancuso went into hiding, and in 1997 the Constitutional Court declared unconstitutional numerous aspects of Decree 356 of 1994, stripping the Convivir of many of their functions of control and vigilance, prohibiting them from collecting intelligence from security forces and from receiving military-issued weapons, and barring the formation of new groups (Valencia 2007, 23). Despite the fact that existing Convivir were not dismantled and continued to enjoy legal status, the judicial branch of the state became more vigilante of their activities and failed to renew many of their licenses, causing all of the leaders to defect directly to the AUC (Valencia 2007, 23).

In 1994, 373 municipalities, or one fourth of the country, were estimated to have a paramilitary presence (Cubides 1999, 176). At that time, the paramilitaries were disorganized and disaggregated death squads. They had no unifying ideology, the rhetoric was underdeveloped and unconvincing, and they spent most of their time in-fighting over the issue of the drug trade and extradition to the United States. In their endeavor to establish themselves as proper (illegal) armies and control larger tracks of territory, the paramilitaries specifically studied what they considered to be the successful political and military development of the guerrilla in order to imitate guerrilla strategies and language (Cubides 1999, 154). By the late 1990s, some paramilitary leaders, like Carlos Castaño, showed a penchant for public interviews, establishing a high public profile, while the paramilitaries organized themselves into irregular armies, or "armed bureaucracies" rather than mere disaggregated death squads (Cubides 2005). The paramilitaries convened three national conventions between 1994 and 1997, culminating in the creation of their umbrella organization, the AUC. Starting in July 1997, they began to publish a bulletin, with a crossword puzzle, ecological page, and even a pedagogical section concerning human rights. The paramilitaries developed a comprehensive rhetorical strategy in order to justify their privately motivated actions in a public context (Cubides 2001, 140-5). This paramilitaries rhetoric consists of three main pillars: 1. The AUC are counter-insurgency forces responding to guerrilla threat 2 . They target civilians because the guerrilla disguised themselves in the civilian population 3. They are self-defence forces, securing their own right to safety and private property where the state is weak and cannot provide security. From 1997-2003, the paramilitaries grew rapidly, expanding into significant portions of the national territory as a response to the FARC negotiations and safe zone in Caguán (Valencia 2007, 8). In 1997, there were approximately 4,000 paramilitary troops, by conservative estimates, and by 2002, that number had risen to 12,000 (ICG 2007, 4). This rapid expansion was made possible by a massive infusion of money, $70 \%$ of which came from drugs, with the remainder coming from selling stolen oil on the black market, extortion, and the plundering of public monies from municipal budgets, bus contracts, the health system, gambling operations, and construction projects, among others (ICG 2007, $5){ }^{9}$

8 President Samper thought it prudent to appoint him National Security Advisor anyway (Avilés 2006, 398).

9 The AUC is responsible for 90\% of stolen oil in Colombia, worth 106 million USD in 2002 (ICG 2007, 4). It also engages in extortion of local businesses and residents. Chiquita Bananas, for example, paid 1.7 million to the AUC for "security" provision between 1997 and 2004 (ICG 2007, 4). 


\section{Targeting Civilians}

Despite their rhetoric of being at war with the guerrilla insurgency, it must be emphasized that the paramilitaries are not traditional war actors. The paramilitaries and guerrilla are neither symmetric in their tactics nor involved in a "mimetic mirror game" (Gonzalez/Bolivar/Vazquez 2003, 75; Cubides 1999, 2001, 2005). Rather, their activities differ drastically in both kind and quantity. Paramilitary forces do not engage in battles against either the guerrilla or the military, but fight their war against the civilian population, engaging systematically in the torture, assassination, and massacre of civilians. According to González, Bolívar and Vázquez (2003, 103-105) the death squads did not engage in a single "war" activity, be it battle, armed confrontation, or even sabotage, with either guerrilla groups or the state between 1990 and 1996. At the height of their power and expansion in 2000, the paramilitaries engaged in merely 58 battles. In comparison, the FARC engaged in 530 battles with the state or other armed groups in 2000, while even the smaller and weaker ELN had 407 battles. The Armed Forces engaged in 414 battles in the same year. Throughout the 1990s, the death squads were participants in merely $1 \%$ of any war activity occurring among armed actors in Colombia (González, Bolívar and Vázquez 2003, 103-105). Thus the death squads are the only armed actor that systematically does not fight other armed actors, instead targeting civilian populations. "The paramilitaries sought to make up for their numerical, organizational, and logistical shortcomings in comparison to the guerrilla by making their primary target the unarmed (civilian) population," (Cubides 1999, 163). Their failure to engage in armed combat with the guerrilla has lead several scholars to conclude that the paramilitaries, despite individual exceptions, were overwhelmingly motivated by personal enrichment, increasing political power, and negotiations with the state that ceded additional material and political benefits, rather than a desire to save the country from the guerrilla (Valencia 2007, 24).

While not actively participating in the war among other armed actors, the paramilitaries quickly replaced the military as the principal human rights abusers in Colombia upon the adoption of the 1991 Constitution (Comisión Colombiana de Juristas 2004). By 1996, the government's own studies reported that paramilitaries were responsible for the vast majority of homicides in the country: "Between 1988 and 1995, 19,631 people were assassinated by organized violence in the country, 2,937 by the guerrilla and 16,694 by non-guerrilla armed organizations servicing various interests. It is clear that paramilitary organizations of drug dealers and private justice holders are primarily responsibility for these deaths," (as quoted in Cubides 1999, 176). Throughout the 1990s, the paramilitaries were responsible for approximately $70 \%$ of all "political" assassinations and 2-3 times as many forced displacements as the guerrilla (Avilés 2006, 384; 403). Forcefully displacing rural citizens from their lands and homes as a tactic of war and land consolidation is so prevalent that by the end of 2006, nearly 4 million people were internally displaced in Colombia, the highest number in the world, surpassing even the Iraqi IDP of 3.5 million (UNHCR 2006, 26; Sanford 2004, 261). ${ }^{10}$

10 As with the use of anti-personal landmines, internal displacement has not followed the overarching reduction in violent crime since 2003, instead increasing steadily since 2002 . 38.52\% more people 287,581 persons or 61,182 households - were displaced in Colombia during 2004 than 2003, and more than 200,000 people were forcefully displaced in 2006 alone (UNHCR 2006). Between 1999 and 2004, there was an average of 77,692 people displaced per quarter, or 863 people every day (UNHCR 2006). 
The paramilitaries established extermination camps where victims were tortured, killed, and dismembered. They burnt towns, destroyed essential infrastructure, and tortured victims, gouging out eyes, cutting out tongues, castrating, crushing victims' heads with rocks and sludge hammers, gang raping women, and suffocating children with plastic bags. ${ }^{11}$ In the last decade alone (1996-2006), paramilitaries are known to have killed at least 14,677 people, not including murders for which attribution is not yet certain, the thousands of bodies currently being exhumed from mass graves, or the disappeared. Paramilitary incursions into new areas are marked by massive civilian displacements, massacres, and selective public tortures and executions, followed by permanently elevated levels of violent crime; not just during struggle for control over territory (Valencia 2007, 20-21; Salazar 2007, 72-3). ${ }^{12}$

Paramilitaries use violence as a way to expand land ownership and "alter the previous order and replace it with another emerging one," (Gonzalez/Bolivar/Vazquez 2003, 62). As part of their expansionist efforts, paramilitaries do not merely defend their own private property, but rather use violence to actively push current owners off land and thus acquire it through illegal means. Throughout the 1990s, agricultural land became one of the primary investments to launder drug monies, and the most efficient way to build a concentration of wealth was to force people to leave their land (ICG 2003, 11). Between 1995 and 1999, 1,738,858 hectares of land were abandoned by small proprietors (Rojas 2001). According to one estimate, as many as 6 million hectares changed hands from 1985 and 1995 in what is commonly now called the "reverse agrarian reform" (Reyes/Gómez

11 In San Onofre, paramilitaries established an extermination camp where victims were taken to be tortured, killed, and buried in mass graves. In the massacre of El Aro (October 25-26 1997), soldiers maintained a perimeter around the town for two days, refusing to let villagers flee while paramilitaries tortured and killed at least 11 people including three children, cutting of the tongues, testicles, breasts, and eyes of victims. Thirty more were "disappeared," and the town's infrastructure destroyed, 47 of the 58 houses in town burned to the ground and even water pipes for potable water destroyed. In El Chengue massacre (January 17, 2007) paramilitaries killed 26 men by crushing their heads with stones and sludge hammers, including a 16-year old boy, his head severed from his body. Again, the area was sealed off by military forces who refused to protect the local population or even allow them to flee. The paramilitary forces had told town residents they were going to kill them months ahead of time, and town residents had reported threats and abuses to the police and military. Even on the very week and day of the massacre, local residents and police phoned the military with license plates numbers, whereabouts, and number of paramilitaries approaching their town, and the military did nothing. In El Salado, Bolivar massacre (February 18-19, 1999) paramilitaries set up a kangaroo court, "trying" local residents. The tortured, garroted, stabbed, decapitated, and shot residents. A six-year old girl was tied to a pole and suffocated with a plastic bag, and at least one woman was gang-raped. Pieces of at least thirty-six bodies were found immediately and another 30 were "disappeared." "To them, it was like a big party," a survivor told the New York Times. "They drank and danced and cheered as they butchered us like hogs," (as quoted, Haugaard 200,4). Again, the Navy prevented the Red Cross from entering until 30 minutes after the paramilitaries had left. In the massacre of Mapiripan (July 1997, 5 full days), 30 residents were killed over the span of five days, even while a local judge sent daily urgent messages describing scene to the military. In a 1997 interview with the newspaper El Tiempo, Carlos Castaño is quoted as stating, "There are going to be a lot of massacres like that in Mapiripan." (Va a haber muchos mapiripanes," (September 28, 1997, quoted here Cubides 1999, 186).

12 This reality differs widely from the paramilitary discourse. Paramilitaries state that during the initial incursion, they seek to liberate areas under guerrilla influence. Subsequently, they say they will consolidate their power and wealth by concentrating the civilian population in urban centers and generating jobs, and finally their power will be legitimized through the expansion of capitalism and the provision of state-like goods (González/Bolívar/Vázquez 2003, 62). 
1997). "Drug traffickers bought the best land. [...] Many drug traffickers became landowners and decided to organise self-defence groups, and converted them into private armies. [...] Their counter-insurgent participation against the guerrillas guaranteed them the necessary complicity of the authorities for their business, security regarding the military forces and the police and impunity regarding the judicial system," (Reyes 1996). ${ }^{13}$ The result of this process of displacement and possession is extreme land concentration in which .4 per cent of landowners own 61.2 per cent of the arable land in the year 2000 (Fajardo 2002).

Rather than compensating for their numerous structural disadvantages through the Maoist doctrine of out-thinking the opponent 10:1, the paramilitaries "sought to compensate for their numeric, organizational, and logistical inferiority to the guerrilla by making its primary target the unarmed civilian population," (Cubides 1999, 163). Instead of fighting the guerilla forces, the paramilitary troops sought to buttress their endangered class positions through terror. They were so successful at skewing the origins of the violence and blurring the lines of causality and culpability (Giraldo 1996; Gamboa 2001; Taussig 1997, 2003), that by the end of the 1990s, there was an overwhelming consensus that the violence was not a product of the armed conflict, but "generalized" social violence that stemmed from cultural dysfunctions not limited to the armed conflict (Bergquist, Peñaranda, and Sanchez 2001). This belief in "generalized" violence reinscribes false borders between political, social, and economic violence, denying the political nature of local relations while sanitizing the political of all personal or economic interests. Paramilitary kingpin Carlos Castaño precisely detailed the indivisibility of violence in his narrative of how the AUC decided who should be assassinated in a massacre and who not. Informants would give him names to put on a hit list. "But what happened a lot was that Mr. X would give me "Albert Restrepo's" name. But maybe they had a business together and Restrepo owed Mr. X money, or maybe Restrepo had slept with Mr. X's wife or even had a run in with him," (Caycedo 1996, 167). Local interpersonal or political relations often take advantage of national violence narratives or political cleavages in order to enact violence while being coded as "political" instead of "personal" (see Das 2000; Roldán 2002). Thus arguing that the violence is "generalized" and thus "social" or "economic" as opposed to political, negates both the political nature of the daily interactions and the way in which all politics is understood and acted out locally. Most importantly, however, it implies that there is no political solution to the violence because it is a cultural phenomenon (Sanford 2004, 264-5).

\section{Para-politics and Demobilization}

While the "para-politics" scandal didn't erupt until late 2006, the paramilitaries, like the guerrilla, had long practiced the Marxist mantra of "the combination of all forms of struggle" (la combinación de todas las formas de lucha), meaning a combination of ille-

13 Paramilitary chief Carlos Castaño describes this process of land concentration in his own words: "We had just given away sixteen thousand hectares in the Sinú. We bought [these lands] cheaply because the guerrillas were there. Look, it's like this: you buy when there are guerrillas, [the lands] aren't worth anything then because all the cattle ranchers have left and there we bought cheaply; then we eradicate the guerrillas and, when the zone is liberated, we give away the lands," (Castro Caycedo, 1996, 201). 
gal violence with both legal and illegal electoral politics (Cubides 2005, 90). As early as 1988, paramilitaries in the Magdalena Medio had formed their own political movement, MORENA. Paramilitaries were also well represented in the Constituent Assembly of 1991 (Cubides 2001, 139). So the formal 2001 accord signed among AUC leaders and numerous politicians should have been of little surprise.

Indeed, Alvaro Uribe won the presidency in the 2002 elections, riding upon the complete collapse of the two-party system and the rise of paramilitary social movements. ${ }^{14}$ Uribe immediately announced his administration's willingness to negotiate with any armed group, including the paramilitaries, as long as it met his preconditions of entering a ceasefire, ceasing the murder and abduction of Colombians, and withdrawing from drug trafficking. Law 782 of 2002 gave the national government the ability to negotiate and enter into peace agreements with illegal armed groups for an additional four years, while eliminating several requisites that illegal armed group previously had to meet in order to enter into negotiations with the state, including the necessity of the official recognition of the group's political status by the government (see Laws 418 of 1997 and 548 of 1999). ${ }^{15}$ Uribe appointed a six-member exploratory commission headed by High Commissioner for Peace, Luis Restrepo, and charged it with establishing contacts and trust with the paramilitaries in order to embark on formal peace negotiations (ICG 2003, 1). The President offered the paramilitaries a safe zone on a large ranch, Santa Fe de Ralito, where they could congregate to negotiate a peace process with the government without fear of arrest.

The United Self-Defense Forces of Colombia (AUC) declared a unilateral ceasefire on December 1, 2002. Their leader, Carlos Castaño, launched a publicity campaign, condemning drug trafficking or ordering several AUC fronts to cut their ties to the drug trade in an active attempt to redefine the AUC as actors in the armed conflict and their motivations as political, despite the legal irrelevance of such a move (see AUC "Declaración por la paz de Colombia," November 29, 2002). The paramilitaries continued to operate in zones of influence, however, committing crimes from the safe zone ranch, including ordering assassinations and brokering drug deals, as well as leaving in order to participate in criminal events. Regardless of these well-known transgressions, the government signed

14 Running on a law and order platform, Uribe won over $50 \%$ of the vote on platform of militarization, rejection of Pastrana's negotiation. The 2-party system collapses. In 2002 elections, Liberals and Conservatives combined get less than half of the seats, while new fragmentations of para-parties and movements gain more than half - 31 - of the seats; 26 senators were elected from para-held zones; 1,741,947 votes (Valencia 2007, 30). Despite the $2 \%$ threshold implemented to reduce this fragmentation and the para-political "scandal" in 2005, paramilitaries elect even more representatives in 2006, taking 33 senators, 50 reps and 1,845,773 votes (Valencia 2007, 30). Even those publicly identified in the para-political scandal are re-elected (Valencia 2007, 48). The first thing Uribe did was to declare state of siege, which granted special powers to the police and military, including the ability to search and arrest without a warrant, and consolidated power in the executive, particularly through the power to legislate through decree. Uribe subsequently decreed zones of rehabilitation and consolidation, curfews, mandatory identification checkpoints, network of paid civilian informants, and even elaboration of the Peace and Justice Law.

15 Senator Rafael Pardo opposed granting the paramilitaries political status and amnesty, arguing instead for following both precedent and law and not negotiating with violent gangs who had not larger political project than their own personal enrichment, but rather application of justice (Valencia 2007, 44). Yet even before Uribe's decree eliminated the need for political status, the question in this case was always an ethical rather than political one. 
the "peace accord" of Santa Fe de Ralito with the AUC on July 15, 2003 and the formal "peace process" began.

The product of the 2003 negotiations with the paramilitaries, the "Peace and Justice Law," (Law 975) was passed by a Congress dominated by the president's party in June 2005. During that time, paramilitary leaders Ernesto Baez, Salvatore Mancuso and Ramón Isaza appeared before the Colombian Congress to lobby for their case. The legislation legalized the process and offered very attractive incentives to the paramilitaries to participate in the demobilization. The law met all the paramilitary's social, political, and economic demands, ensuring they did not have to confess their crimes, disclose information about how their groups operate, turn over illegally acquired wealth, or spend more than six months deprived of their freedom, even for crimes against humanity, after deducting the time spent on the finca as jail time. Finally, if convicted, they would serve their six months on "agricultural colonies," not in jail.

There were numerous legal challenges to this law by victims. In July 2007, the Supreme Court ruled the Justice and Peace Law constitutional, with several conditions. The Court stipulated that ex-combatants risked losing benefits if they did not confess all crimes, return all ill-gotten goods, and pay reparations to victims. Moreover, insurgents are legally liable for all crimes committed by their blocs. The decision reiterates the state's responsibility to ensure victim reparations if ex-combatant's assets are insufficient, and requests that victims have full access to information throughout the legal process. Finally it gives judicial authorities additional time to investigate and verify confessions (Sentence C-370-2006).

On August 14, 2006, in face of mounting public criticism regarding evidence that the paramilitary leaders continued to commit crime from their low-security prison, La Ceja, Uribe ordered the AUC high commands first to be placed in temporary seclusion and later to be transferred to a high-security prison in Itaguí. Displeased with the move, several paramilitary leaders announced they were withdrawing from the peace process. The paramilitaries continually complained about their shoddy treatment throughout the process. On November 6, 2006, the prominent weekly magazine Semana published a letter from Vicente Castaño to the High Peace Commissioner Restrepo, complaining that the government had failed to create a legal framework that would prevent any paramilitary from being extradited to the United States, to legislatively override the Constitutional Court's amendments to the Justice and Peace Law, to incarcerate them only after a legal tribunal had sentenced them, and not while under investigation or after a guilty verdict but before sentencing, and to allow the year and a half the spent on the farm to count as one third of any sentence (Valencia 2007, 49). Disgruntled with every minimal effort at reducing impunity and seeking justice, the paramilitaries returned to arms en masse. Vicente Castaño was said to have 5,000 men armed and organized in a militia, when Uribe finally ordered 59 of the top leaders to high security prison in Itaguí, La Ceja (Valencia 2007, 49).

By the end of 2006, the government claimed that 32,000 paramilitaries had demobilized.

This number was far superior to that anticipated. ${ }^{16}$ A year later, that number had risen to 43,000 demobilized combatants - 31,670 in the collective AUC demobilization, and

16 A "significant part" of paramilitaries who demobilized in December 2005 and April 2006 were testaferros (front men) that wanted to enjoy the benefits of the "Peace and Justice Law". Testaferros tried to legalize their holdings, so paramilitaries stopped turning over stolen land and money to the state 
11,772 individually: 6,285 FARC; 3,548 AUC; 1,592 ELN, and the rest from other armed groups (ICG 2007, 23). 29,000 of the paramilitaries that demobilized collectively filled out a short survey consisting of their role in the death squads. According to the InterAmerican Commission on Human Rights, $90 \%$ of these surveys "offered no significant information on illegal acts or crimes committed by the paramilitary units to which they belonged," (as quoted Haugaard 2008, 5). Afterwards, they were given state identification (cédulas) and evidence of military service - whether or not said service had actually been completed, thus in essence recognizing participation in a paramilitary death squad as military service - and registered for the "reincorporation" package which consists of stateprovided food and housing, education, government subsidies or paychecks for two years free of work, and state health benefits including psychological counseling. ${ }^{17}$ Only 3,127 of the most notorious paramilitary members, fearful of possible extradition to the United States given their high profiles and public disregard for the law, applied for the "reduced" sentences by giving voluntary depositions (versiones libres) regarding their illicit activities. ${ }^{18}$ The top commanders who gave their voluntary testimonies before being extradited unexpectedly to the United States justified their crimes as necessary, claimed to not remember the details of their crimes, declared themselves paupers and unable to restitute their amassed wealth, and displayed the extent of their power and impunity by mobilizing supporters to turn the depositions into celebrations in their honor, throwing confetti, dancing to music, and threatening victims, much as they did during the massacres they committed. ${ }^{19}$

Paramilitary wealth, political power, and criminal networks were left intact upon their "demobilization" (Avilés 2006, 406). Few have turned from a life of crime and violence. From the start of the ceasefire in December 2002 until June 3, 2007, paramilitaries committed 3,530 murders or disappearances outside of combat. Guerrilla groups, who were not demobilized and were in active combat, killed 1,805 civilians during the same period. In essence, demobilized paramilitaries continue to kill nearly twice as many civilians as guerrilla still in combat (Haugaard 2008). They still threaten unions, human rights acti-

for victim reparation. Also, the public prosecutor's office decided not to investigate illegally gotten goods held by testaferros (Salazar 2007, 60).

17 The state distributed 862 identity cards and 420 military service records. 200 more were being processed. The Department of Security Administration (Departamento Administrativo de Seguridad, DAS) awarded 639 certificates. The Ministry of the Interior and Justice runs the Program for Reincorporation to Civilian Life which grants economic benefits to all ex-combatants for up to two years, while humanitarian aid is granted until their reinsertion is complete (Decree 395 2007). In reality, much of this aid is not being delivered: only $28 \%$ of the demobilized have received counseling, $46 \%$ have basic health coverage, $23 \%$ obtained occupational training, and $10 \%$ accessed higher education. Only $26 \%$ of the demobilized have jobs, mostly in private security companies. Ex-combatant frustration is high - they protest against a lack of security and job opportunities, and against stigmatization (ICG 2007, 24).

18 Sentences were capped at eight years and the time the paramilitaries spent on protected farms while they negotiated the agreement was to be deducted.

19 In their testimonies (versions libres) Jorge 40 opened with lengthy explanation of why self-defense groups were necessary due to the guerrilla threat and peasant marches. Victims, corralled in another room after traveling long distances to find answers to disappeared loved ones, were not even allowed to ask questions. Their testimony was suspended after they became "desperate' and protested. Roman Isaza claimed to have first amnesia then Alzheimer's, and asked his victims to help him remember his crimes. Macaco Carlos Mario Jimenez claimed, that he and his men were possessed by spirits "in pain" that drove them to kill. Freddy Rendón (El Aleman) bussed in supporters and sympathizers who threw flowers, provided musicians and dancers and confetti. Rendón appeared at a $6^{\text {th }}$ floor window, saluted his "fans" and shook his hips to the music below. 
vists, community leaders, and paramilitary victims seeking restitution, and they still receive support from Colombian soldiers and police. By September 2007, 15 paramilitary victims had been murdered and 200 more threatened by demobilized paramilitary groups. ${ }^{20} 1,070$ paramilitaries have been arrested since being demobilized, though only $17 \%$ in conjunction with continued paramilitary activities; the majority had committed petty crimes, often in conjunction with urban gangs, in exchange for money (ICG 2007, 22). Between 474 and 1,000 ex-combatants have been killed, predominantly in relation to continued criminal activities (ICG 2007, 22). After Salvatore Mancuso announced that 5,000 of his men had rearmed, Frank Pearl, the High Counselor for Reinsertion, was forced to admit publicly that his office did not know the whereabouts of 4,731 demobilized fighters (ICG 2007, 23). Since June 2006, the police have been charged with producing a monthly report on the ex-combatant's activities and are working with the DAS to set up a protection program (ICG 2007, 22).

New groups have formed throughout the country to fill the power vacuum. Some of these groups are headed by paramilitary leaders who did not demobilize like Vicente Castaño and Martin Llanos and some receive orders from imprisoned paramilitaries like Macao, while others are led by mid-ranking AUC who took up arms again, and the remainder are the armed wing of drug trafficking organisations that have existed for years (ICG 2007, 1). Security force commitment to fighting the new groups is low, in part because the FARC is the priority but also because drug-related corruption is taking a toll (ICG 2007, 1). They continue to be linked to drug trafficking and criminal networks, though their control of regional politics and economics is far less pervasive and they have largely refrained from political or ideological causes, like counterinsurgency (ICG 2007, 2-3). "Don Berna" still controls Medellín, and Vicente Castaño, who did not demobilize is believed to be rebuilding part of the AUC in old area of influence in Urabá, where significant recruitment has been reported (ICG 2007, 20).

Yet there is no sign that justice has been or will be done. Over the course of four years, the justice system only managed to start depositions on 1,057 of the assassins, 941 of which were closed, because the paramilitaries withdrew from the process, as the inefficiency of the justice system offered a probable way to escape even eight years in jail (Haugaard 2008). "The chronically overburdened and notoriously slow justice system is having difficulty in reacting to the threat of the emerging groups and organized crime at

20 According to the state CNRR (National reparation and reconciliation commission), at least 15 victims seeking justice have been killed by September 2007 and another 200 have been threatened. Paramilitaries have an extermination list with 26 victim names on it. Yolanda Izquierdo, a displaced leader demanding her land to be returned to her, was murdered on January 31, 2007 after testifying in Salvatore Mancuso's hearing. She had previously gone weeping from one government agency to another, demanding protection for death threats she had been receiving for weeks; She went to the Attorney General's office, the Ombudsman's office, the DAS intelligence agency, the Inspector General's office, and the local attorney general, who told her he couldn't do anything, and to "come back on Friday." Carmen Cecilia Santana Romana (February 7, 2007) had testified in front of the National reparation and reconciliation commission, demanding reparation for the killing of her husband and making human rights claims for the union Sinatrainagro. She was killed in front of her house and three kids, ages 7, 9, and14. Judith Vergara Correa advisor to a victims group, Madres de la Candelaria, was similarly murdered on April 23,2007 . The state only produced a witness protection plan in 2008 upon court order. Victims associations have been broken into and registries of victims stolen, and the government has failed to investigate or even denounce these crimes. 
the same time as it is trying to cope with implementation of the JPL. Crisis Group heard recurrent complaints by justice sector officials in several regions about precarious working conditions and insufficient resources to conduct criminal investigations in a thorough and timely manner and lack of cooperation from the security forces. Pervasive fear was felt in places such as Nariño, Norte de Santander and Magdalena departments, not least because of a record of paramilitary infiltration of state institutions," (ICG 2007, 21). "How far the heavily burdened legal system will take these matters remains to be seen. While the Supreme Court is investigating many of the cases, it is the attorney general's office that must collect evidence, and it has limited resources," (ICG 2007, 22).

Moreover, paramilitaries seem to have successfully transferred their source of power to legal political structures. By 2006, it was widely reported that more than $30 \%$ of congress earned votes "illegitimately" from paramilitaries or otherwise had connections to the death squads (Valencia 2007, 52). Sixty-three politicians were under active investigation of paramilitary collaboration by 2007 , while other unelected top officials appointed by President Uribe were similarly asked to resign, facing criminal charges, or implicated in the "para-political scandal." 21 Yet there have been few convictions while the investigations stagnate, and in the passing time, the electoral popularity of many of the paramilitary movements and candidates has merely increased (Romero ed. 2007; Gavíria 2008).

\section{Future Research Agenda: Silences, Biases and Conclusions}

In this section I would like to set an agenda for future research by highlighting three major silences and one theoretical tension in the current studies of paramilitarism in Colombia. First, these studies are marked by an overreliance on paramilitary discourse, official transcripts, and public interviews with top paramilitary leaders. With the notable exception of Taussig (1997, 2003), few studies document how all sorts of regular people - victims, local residents, family members, politicians, local businesses and other daily actors - negotiate these very high stake political allegiances. How do local people understand the violence inflicted by paramilitaries, their rule, and their presence? What strategies do they use to coexist with paramilitary presence, and how do they go about normalizing, supporting, or resisting paramilitary presence? Why were more "para-politicians" elected in 2006 after the "para-political scandal" broke than in 2002, including the reelection of several prominent para-politicians actively under investigation at the time? What motivated so many people to go and express public support for the paramilitaries as they gave their "truth" statements (see Haugaard 2008)? There is a need for a nuanced understanding of the popular support of the paramilitaries that avoids pathologizing regular people while moving beyond explanations of mere tolerance or cowed complacence. There is also a need to understand the way in which the presence of paramilitaries affected people's daily lives and how common people negotiated very dangerous political boundaries.

Secondly, there is a need for a careful and nuanced discussion of political culture, political economy, and the intersections and tensions between the two. After extended peri-

21 Jorge Noguera, the head of the nation's top intelligence agency (DAS), who was forced to resign when his own paramilitary activity was exposed and investigated. 
ods of irregular war, what does it mean to return to normalcy? What does it take to successfully demobilize thirty or forty thousand combatants, many of which have committed gross crimes against humanity? To consider these questions, we need careful studies of the current political culture that take into account the ways in which culture changes and the impact of decades of violence on particular communities. Studies of political culture in Colombia have long been discarded by creating straw arguments against even thinking of a "culture of violence" that has been passed down since colonial times. It is precisely because political culture is flexible and pliable that we need to understand how violence functions in society, its meanings, symbolism, and power, in order to address it as a problem. Finally, given the failure to demobilize combatants who reportedly return to a life of crime because of lack of employment opportunities, the intersection of political economy and political culture must yet again be analysed in this specific context. It might be very likely that poverty has less to do with origins of the violence than its ends, or lack thereof.

The third silence in the current literature is closely related to that of political culture. It is that of gender and sexuality. Reports consistently mention the way in which paramilitaries target prostitutes, transsexuals, and the GLBTQ community for harassment, torture, disappearance, and assassination, while enforcing strict compliance with normative gender stereotypes in terms of dress and comportment. Similarly, the sexualized nature of the torture carried out by paramilitaries, including the mutilation of male and female genitalia, the destruction of pregnant women and their fetuses, and the systematic rape of women has also been documented (Amnesty 2004). That these forms of sexualized violence are used as war crimes exclusively by the paramilitary troops, and not by the guerrilla, has gone almost without comment (Wood 2006). According to estimates, approximately $30 \%$ of FARC soldiers, but only $2-4 \%$ of paramilitary fighters, are women (Tate 2007, 54). Around 6 per cent, or 2,000 of the demobilized AUC, are women. These women have special reintegration needs that have not even been identified, much less met (ICG 2007, 1). Women as combatants have been erased, with no special programming, while efforts are being made to create specials programs for the wives of combatants (ICG 2007, 23). Given these preliminary statistics and these systemic silences and erasures, scholars need to prioritize sensitive and comprehensive research on how the construction of particular masculinities have contributed to the armed conflict, with particular attention to the differential between the guerrilla and the army/paramilitaries, as well as conscious efforts to avoid the pathologization of poor masculinities by explaining the origins of people's gender and sexual stereotypes rather than perpetuating them (e.g. Moser/McIlwaine 2004).

Finally, much of the current research reinscribes problematic dichotomies that difficult serious analysis and theory building. Here I will point out just two, although the problem is recurring through the literature. First, there is a continual creation of an urban-rural binary, in which the urban is prioritized as the site of learned citizens, the state, peace, and modernity. This urban center, the City-State, is under constant attack by the barbaric and uncontrollable outlying regions (Hunt 2006). This is a common trope in which, "regional political elite, in their hurry to resist the democratic changes at the national level and the efforts to negotiate with the guerrilla, also need to be backed up by an illegal armed actors, display the clear intention to find this backing, and they are disposed to respond to some of the paramilitary's demands," (Valencia 2007, 12). Many authors position Bogotá alone as the site of national modernity and democracy, attacked by "subnational authoritarianism" (e.g. Gibson 2006). Backwards and undemocratic people from outside of Bogotá are described as undermining these "more learned and educated leaders (los liderazgos más cultos e instruídos) from Bogotá" (Valencia 2007, 28). "Behind the 
interests of a new elite of "señores de la Guerra" is the tension between urban forces that are trying to construct a society guided (regida) by democratic principles and modern capitalism versus rural forces that want to disperse the power of the state in order to construct regional governments based on the immunity of criminal businesses,"(Duncan 2005). This spatialization of state creates a false dichotomy and impedes an adequate understanding of either the state or social relations that would permit a comprehensive theory of paramilitarism.

Finally, this case also illustrates the problematic reinscription of a conceptual binary between state and society. As this case demonstrates empirically, the paramilitaries transcend the boundaries between state and society. Attempts to explain the paramilitaries invariably draw on more global discourses that posit the problem of unchecked violence either in the realm of the state or that of society. There are those who argue that violence in Colombia is due to state failure to control it. This failure might stem from any variety of variables, such as lack of international conflict (Centeno 2002), presidential instead of parliamentarian systems (Linz 1994), and narrow-minded, selfish elite who foster popular identification with particular political parties rather than the state itself and undermining national identity (Pécaut 1987, 2001; Fischer 2004, Palacios 1990; Restrepo 2004; Sousa Santos/Garcia Villegas 2004; Bushnell 1993; González 1989; González/Bolívar/Vásquez 2003; Posada Carbó 2006). Alternately, many scholars disappointed with democracy and disenchanted with the state, have moved their analysis squarely onto the shoulders of civil society (e.g., Tulchin/Ruthenburg 2007; Yashar 2005; Bermeo 2003). Violence, in particular, is thought to be a social phenomenon, unconnected and unpreventable by the state (Moser 1998, 2000; Laitin 1995; Varshney 2002; Godoy 2006; Sudarsky 1999, 2001; Londoño 1998). ${ }^{22}$ Weak civil societies are blamed for generating "dangerous populisms," anti-democratic conservatism, and Mafioso societies shrouded in violence and lawlessness (Gibson 1993, 1994, 2001; Howard 2003; Sudarsky 1999, 41). In Latin America, "citizens are not so much seen any longer as agents of democratization, but rather as part of the diagnosis of shaky democracies [...] Ordinary people [...] represent the gravest threat to democracy today in Latin America," (Hagopian 2007, 19; 110). The Colombian state has willingly followed suit: "We depart from the conviction that security is not only a police problem; moreover, it is not only a state problem. Learning to resolve conflicts peacefully, to make one responsible for his/her personal security and own life and that of others while avoiding behaviors that put it [their life] at risk, and collaborating with other citizens or with the authorities in order to detain criminal or terrorist activities are all jobs that correspond to citizens and that have a great impact in terms of protecting life," (Presidencia 2006, 15). Yet this case disproves the understanding of state and society as separate spheres, and violence or the push toward privatized justice as stemming from one or the other. The Colombian paramilitaries cannot be understood as either a tool of a terrorist state or the product of an uncontrollable civil society that victimizes the state. They are

22 The relationship between social capital and violence in this literature is not clear. Some argue that violence depletes social capital (Moser 1998; 2000), while others argue that low social capital engenders violence (Laitin 1995; Varshney 2002), and yet a third faction is forthcoming about the circular nature of their argument, simply stating that violence depletes low social capital which in turn creates more violence in a never-ending spiral (Godoy 2006; Sudarsky 1999, 2001; Londoño 1998). 
instead a form of contemporary governance that inseparably links state and citizen construction and unfailingly transcends suspected state and society boundaries.

The study and understanding of privatized forms of violence and security is yet incipient. Even after their demobilization, much is left unknown about the Colombian paramilitaries. In this paper, I have evaluated the existing state of the literature on paramilitarism in Colombian, pointing out silences and areas for future research. I have argued that the paramilitaries consist of an uncomfortable amalgam of interests with a highly political agenda. I have detailed the legislation and decrees that created a space of legal ambiguity and flexibility for the development of the paramilitaries. I illustrated the ways in which the paramilitary forces differed from other forces, in particularly the guerrilla, by the quantity and quality of their human rights violations as a result of their policy of targeting civil society. The paramilitary's long involvement in politics paid off in their demobilization and subsequent incorporation into political life. I ended this essay by highlighting three areas of necessary research and two theoretical roadblocks to our understanding of paramilitarism and privatized security and violence. Understanding the role these processes play in the ever-rising levels of violence in Latin America will be essential to creating policy solutions to this problem.

\section{Bibliography}

Agamben, G. (1998) Homo Sacer: Sovereign Power and Bare Life. Stanford: Stanford University Press.

Amnesty International (2004) Scarred Bodies, Hidden Crimes: Sexual Violence Aganst Women in the Armed Conflict. (October 28).

http://web.amnesty.org/library/Index/ENGAMR230402004

Avilés, W. (2006) Paramilitarism and Colombia's Low-Intensity Democracy. In: Journal of Latin American Studies. 38(2): 379-408.

Bejarano, A. M./Pizarro, E. (2005) From 'restricted' to 'besieged': the changing nature of the limits to democracy in Colombia. In: Hagopian, F./Mainwaring, S. (Eds.) The Third Wave of Democratization in Latin America. New York: Cambridge University Press, 235-260.

Benson, P./Fischer, E./Thomas, K. (2008) Resocializing Suffering: Neoliberalism, Accusation, and the Sociopolitical Context of Guatemala's New Violence. In: Latin American Perspectives. Vol. 35, Issue 162, No. 5: 38-58.

Bergquist, C./Peñaranda, R./Sánchez, G. (Eds.) (2001) Violence in Colombia 1990-2000. Waging War and Negotiating Peace. Wilmington, DE: Scholarly Resources.

Bergquist, C./Peñaranda, R./Sánchez, G. (Eds.) (1992) Violence in Colombia: The Contemporary Crisis in Historical Perspective. Wilmington, DE: Scholarly Resources.

Bermeo, N. (2003) Ordinary People in Extraordinary Time: The Citizenry and the Breakdown of Democracy. Princeton: Princeton University Press.

Bowden, M. (2001) Killing Pablo. New York: Atlantic Monthly Press.

Bushnell, D. (1993) The Making of Modern Colombia: A Nation in Spite of Itself. Berkeley: University of California Press.

Caldeira, T. (2000) City of Walls: Crime, Segregation, and Citizenship in São Paulo. Berkeley: University of California Press.

Castro Caycedo, G. (1996) En secreto. Bogotá: Planeta. 
Centeno, M. (2002) Blood and Debt: War and the Nation-State in Latin America. University Park, PA: Pennsylvania State University Press.

Civico, A. (2006) Portrait of a Paramilitary: Putting a Human Face on the Colombian Conflict. In: Sanford, V./Angel-Ajani, A. (Eds.) Engaged Observer: Anthropology, Advocacy, and Activism. New Brunswick: Rutgers University Press, 131-146.

Comisión Colombiana de Juristas (2004) En contravía de las recomendaciones internacionales: "Seguridad democrática", derechos humano y derecho humanitario en Colombia: agosto de 2002 a agosto de 2004. Bogotá: Opciones Gráficas Ltda.

Consultoria para el Desplazamiento Forzado y los Derechos Humanos (CODHES) and Unicef. (1999) Un pais que huye: Desplazamiento y violencia en una nacion fragmentada. Bogotá.

Coronil, F./Skurski, J. (Eds.) (2006) States of Violence. Ann Arbor: University of Michigan Press.

Cubides, F. (2005) Santa Fe de Ralito: avatars e incongruencias de un conato de negociación. In: Analisis politic, No. 53: 88-94.

Cubides, F. (2001) From Private to Public Violence: The Paramilitaries. Chapter 6 in Bergquist, C./Peñaranda, R./Gonzalo Sánchez, G. (Eds.) (2001) Violence in Colombia 1990-2000: Waging War and Negotiating Peace. Wilmington, DE: Scholarly Resources Inc, 127-150.

Cubides, F. (1999) Los paramilitares y su estrategia. In : Deas, M./Llorente, M.V. (Eds.) Reconocer la Guerra para construir la paz. Bogotá: Cerec, 151-200.

Das, V. (2000) The Act of Witnessing: Violence, Poisonous Knowledge, and Subjectivity. In: Das, V. et al. (Eds.) Violence and Subjectivity. Berkeley: University of California Press.

Das, V./Poole, D. (Eds.) (2004) Anthropology in the Margins of the State. Santa Fe: School of American Research Press.

Davis, D./Pereira A. (Eds.) (2003) Irregular Armed Forces and their Role in Politics and State Formation. Cambridge: Cambridge University Press.

Dudley, S. (2004) Walking Ghosts: Murder and Guerrilla Politics in Colombia. New York: Routledge.

Duncan, G. (2009) Las dos versions de la parapolítica. In: El Espectador, November 15 th.

Duncan, G. (2005) Del campo a la ciudad en Colombia. La infiltración urbana de los señores de la guerra. Bogotá: Universidad de los Andes, Documento Cede 2005-2.

Fajardo, D. (2002) Tierra, poder político y reformas agraria y rural. In: Cuadernos: Tierra y Justicia, Vol. I. Bogotá, 5.

Fals Borda, O. (2004) Dimensiones territoriales de la guerra y la paz. Bogotá: Universidad Nacional de Colombia.

Gamboa, M. (2001) Democratic Discourse and the Conflict in Colombia. In: Latin American Perspectives, translated by James W. Zackrison. 28(1): 93-109.

Gaviria, J.O. (2008) Parapolítica, verdades, y mentiras. Bogotá: Centro de Pensamiento Primero Colombia.

Gerring, J. (2004) What is a Case Study and What Is It Good for? In: American Political Science Review 98(2): 341-354.

Gibson, E. (2006) Autoritarismo subnacional: estrategias territoriales de control politico en regimens democráticos. In: Desafios 14, Bogotá: CEPI, Universidad del Rosario.

Giraldo, J. (1996) Colombia: The Genocidal Democracy. Monroe, ME: Common Courage Press.

Godoy, A.S. (2006) Popular Injustice: Violence, Community, and Law in Latin America. 
Stanford, CA: Stanford University Press.

Goldstein, D. (2004) The Spectacular City: Violence and Performance in Urban Bolivia. Durham: Duke University Press.

Hagopian, F. (2007) Latin American Citizenship and Democratic Theory. Chapter 2 in: Tulchin, J. S./Ruthenburg, M. (Eds.) Citizenship in Latin America. Boulder: Lynne Rienner Publishers, 11-56.

Hansen, T. B./Stepputat, F. (Eds.) (2006) Sovereign Bodies: Citizens, Migrants, and States in the Postcolonial World. Princeton: Princeton University Press.

Hansen, T. B./Stepputat, F. (Eds.) (2001) States of Imagination: Ethnographic Explorations of the Postcolonial State. Durham: Duke University Press.

Hardt, M./Negri, A. (2004) Multitude: War and Democracy in the Age of Empire. New York: Penguin Press.

Haugaard, L. (2008) The Other Half of the Truth: Searching for Truth, Justice and Reparations for Colombia's Victims of Paramilitary Violence. Washington, DC: Latin America Working Group Education Fund.

Holston, J. (2008) Insurgent Citizenship: Disjunctions of Democracy and Modernity in Brazil. Princeton: Princeton University Press.

Holston, J./Appadurai, A. (1999) Introduction: Cities and Citizenship. In: Holston, J. (Ed.) Cities and Citizenship. Durham: Duke University Press, 1-18.

Howard, M. M. (2003) The Weakness of Civil Society in Post-Communist Europe. Cambridge: Cambridge University Press.

Hunt, S. (2006) Languages of Stateness: A Study of Space and El Pueblo in the Colombian State. In: Latin American Research Review, 41(3): 88-121.

International Crisis Group (2007) Colombia's New Armed Groups. In: Latin America Report, 20 (May 10)

International Crisis Group (2003) Colombia: Negotiating with the Paramilitaries. In: Latin America Report, 5 (September 16)

Koonings, K./Kruijt, D. (Eds.) (2004) Armed Actors: Organized Violence and State Failure in Latin America. London/New York: Zed Books.

Llorente, M. V./Escobedo, R./Echandía, C./Rubio, M. (2001) Violencia homicida en Bogotá: más que intolerancia. Documento CEDE (Centro de Estudios sobre Desarrollo). 2001-02. Version electronica. Bogotá: Universidad de los Andes.

Medina Gallego, C. (1990) Autodefensas, paramilitares y narcotrafico en Colombia. Bogotá: Editorial Documentos Periodísticos.

Montenegro, A./Posada, C.E. (Eds.) (2001) La violencia en Colombia. Bogotá: Alfaomega-Cambio

Moser, C. (2000) Violence in Colombia: Building Sustainable Peace and Social Capital. A World Bank Country Study. Washington DC: The World Bank, prepared by Caroline Moser and team.

Moser, C. (1998) Urban Poverty and Violence: Consolidation or Erosion of Social Capital. 1996 World Bank Latin American and Caribbean Studies Proceedings: Annual World Bank Conference on Development in Latin America and the Caribbean: Poverty and Inequality. Burki, S.J./Aiyer, S.-R./Hommes, R. (Eds.) Bogotá: 83-88.

Moser, C./Mcllwaine, C. (2004) Encounters with Violence in Latin America. New York: Routledge.

Palacio, G. (Ed.) (1990) La Irrupción del paraestado: ensayos sobre la crisis colombiana.Bogotá: CEREC.

Pearce, J. (1990) Colombia: Inside the Labyrinth. New York: Latin American Bureau. 
Pizarro, E. (2004) Una democracía asediada: balance y perspectives del conflicto armado en Colombia. Bogotá: Norma.

Reyes, A. (1996) El narco-feudalismo armado. In: Estrategia Económica y Financiera, No. 242, (August 31): 36-38.

Reyes, A./Gómez, A.L. (1997) Compra de tierras por narcotraficantes. Drogas ilícitas en Colombia: Su impacto económico, politico y social. Bogotá: PNUD.

Rojas, J. (2001) Desplazados: Lógicas de Guerra, incertidumbres de paz. Desplazamiento forzado interno en Colombia: Conflicto, paz y desarrollo. Bogotá: ACNUR-CODHES.

Roldan, M. (2002) Blood and Fire: La Violencia in Antioquia, Colombia, 1946-1953. Durham: Duke University Press.

Romero, M. (Ed.) (2007) Parapolítica. La ruta de la expansion paramilitary los acuerdos politicos. Bogotá: Corporación Nuevo Arco Iris.

Romero, M. (2003) Paramilitares y autodefensas 1982-2003. Bogotá: IEPRI/Editorial Planeta Colombiana.

Salazar, B.P. (2007) El paramilitarismo en Cundinarmarca y Bogotá, 1997-2006. In: Romero, M. (Ed.) Parapolítica. La ruta de la expansion paramilitary los acuerdos politicos. Bogotá: Corporación Nuevo Arco Iris, 59-107.

Sanford, V. (2004) Contesting Displacement in Colombia: Citizenship and State Sovereignty at the Margins. Chapter 10 in: Das, V./Poole, D. (Eds.) Anthropology in the Margins of the State. Santa Fe: School of American Research Press, 253-277.

Sousa Santos, B./García Villegas M. (Eds.) (2001) El caleidoscopio de las justicias en Colombia. Bogotá: Siglo del Hombre Editores.

Sudarsky Rosenbaum, J. (2001) El Capital Social de Colombia. Bogota: Departamento Nacional de Planeacion; Imprenta Nacional de Colombia.

Sudarsky Rosenbaum, J. (1999) Colombia's Social Capital: The National Measurement with the Barcas. World Bank Document 400219-1150464137254. Bogotá: National Planning Office.

Tilly, C. (1985) War Making and State Making as Organized Crime. Chapter 5 in: Evans/Rueschemeyer/Skocpol (Eds.), Bringing the State Back In. Cambridge: Cambridge University Press, 169-187.

Uprimny, R. (1990) La palabra y la sangre: violencia, legalidad y guerra sucia. In: Palacio, G. (Ed.) La Irrupción del paraestado. Bogotá. CEREC, 105-169.

Uribe, M. T. (2001) Nación, ciudadano y soberano. Medellín: Corporación Región.

Varshney, A. (2002) Ethnic Conflict and Civic Life: Hindus and Muslims in India. New Haven: Yale University Press.

Valencia, L. (2007) 'Prólogo' and 'Los caminos de la alianza entre los paramilitares y los Politicos'. In: Romero, M. (Ed.) Parapolitica. La ruta de la expansion paramilitary los acuerdos politicos. Bogotá: Corporación Nuevo Arco Iris, 7-58.

Wood, E. J. (2006) Variation in Sexual Violence during War. In: Politics and Society 34(3): 307-341. 
Stacey L. Hunt is currently an AAUW American Dissertation Completion Fellow and a member of the 2008-2009 Institute for Research on Women Seminar, "Culture of Rights, the Rights of Culture" at Rutgers University. Stacey Hunt is currently completing a book manuscript on citizen culture, a novel crime reduction policy first implemented in Bogotá, Colombia. She has published in the Latin American Research Review and Society and Space on the spatiality of the relations between state construction and citizenship, and is broadly interested in contemporary state theory and governance.

E-Mail: staceleigh2@gmail.com 